\title{
Uneven patterns in airport seat capacity distribution: a review
}

\author{
Pere Suau-Sanchez \\ Cranfield University. Department of Air Transport \\ p.suausanchez@cranfield.ac.uk
}

Received: May 2012

Accepted: July 2012

\begin{abstract}
This paper reviews the literature on the uneven patterns of airport seat capacity. Seat capacity distribution studies are useful to show air travel possibilities and whether economic development is concentrated in some particular regions. During the last decades, seat capacity patterns have been reshaped by an increasing process of deregulation of the air traffic market and liberalization of the former flagship carriers. Overall, literature agrees that intra-continental seat capacity has tended to deconcentrate, meaning that seats are more equally spread along the airport population, while inter-continental seat capacity, the most valuable for the exchange of face-to-face information and global supply chains, has tended to concentrate in fewer airports. Hence, in quantitative terms inequality has decreased, although in qualitative terms it has increased.
\end{abstract}

Keywords: air transport; seat capacity; unevenness; spatial patterns; deregulation; liberalization.

\section{Resum. Patrons desiguals en la distribució de places aèries: una revisió}

Aquest article revisa la literatura sobre la distribució desigual de places aèries. Els estudis d'oferta de places són útils per mostrar les possibilitats de viatjar i si el desenvolupament econòmic està concentrat en determinades regions. Durant les últimes dècades, els patrons de distribució de places aèries han estat redefinits pels creixents processos de desregularització del mercat del tràfic aeri i la liberalització de les línies aèries de bandera. En conjunt, hi ha un acord a la literatura a considerar que l'oferta de places per a vols intracontinentals ha tendit a desconcentrar-se. És a dir, les places estan repartides de manera més equilibrada al llarg de la població d'aeroports. D'altra banda, l'oferta de places per a vols intercontinentals, els més valuosos per a l'intercanvi d'informació cara a cara i les cadenes de producció globals, ha tendit a concentrar-se en menys aeroports. Així doncs, des del punt de vista quantitatiu, la desigualtat ha disminuït, tot i que en termes qualitatius aquesta s'ha incrementat.

Paraules clau: transport aeri; places aèries; desigualtat; distribució espacial; desregulació; liberalització.

Resumen. Patrones desiguales en la distribución de plazas aéreas: una revisión

Este artículo revisa la literatura sobre la distribución desigual de plazas aéreas. Los estudios de oferta de plazas son útiles para mostrar las posibilidades de viajar y si el desarrollo 
económico está concentrado en determinadas regiones. Durante las últimas décadas, los patrones de distribución de plazas aéreas han sido redefinidos por los crecientes procesos de desregularización del mercado del tráfico aéreo y la liberalización de las aerolíneas de bandera. En conjunto, hay un acuerdo en la literatura en considerar que la oferta de plazas para vuelos intracontinentales ha tendido a desconcentrarse. Es decir, las plazas están repartidas de forma más equilibrada a lo largo de la población de aeropuertos. Por otro lado, la oferta de plazas para vuelos intercontinentales, los más valiosos para el intercambio de información cara a cara y las cadenas de producción globales, ha tendido a concentrarse en menos aeropuertos. Así pues, desde el punto de vista cuantitativo, la desigualdad ha disminuido, aunque, en términos cualitativos, esta se ha incrementado.

Palabras clave: transporte aéreo; plazas aéreas; desigualdad; distribución especial; desregularización; liberalización.

Résumé. Modèles inégaux dans la distribution des sièges aériennes: une révision

Cet article rencontre la littérature sur la répartition inégale des sièges aériens. Les études des sièges sont utiles pour montrer les possibilités de voyage et si le développement économique est concentré dans certaines régions. Dans les dernières décennies, les modèles de distribution des sièges aériennes ont été redéfinis par les processus de croissance de la déréglementation du marché du trafic aérien et la libéralisation des compagnies aériennes de drapeau. Il existe un accord dans la littérature en faisant valoir que l'offre de places aux vols intra-continentaux a tendance à la déconcentration. Autrement dit, les sièges sont répartis de forme plus équilibrée tout au long de la population des aéroports. En outre, l'offre de places pour les vols intercontinentaux, les plus précieux pour l'échange d'informations face to face et les chaînes de production mondiales, a eu tendance à se concentrer sur moins aéroports. Ainsi, du point de vue quantitatif, l'inégalité a diminué, bien que cela a augmenté en termes qualitatifs.

Mots clé: transport aérien; sièges aériennes; inégalités; distribution spatiale; déréglementation; libéralisation.

\section{Summary}

\begin{tabular}{|c|c|}
\hline $\begin{array}{r}\text { Introduction } \\
\text { Deregulation and liberalization }\end{array}$ & $\begin{array}{l}\text { Towards concentration or } \\
\text { deconcentration? }\end{array}$ \\
\hline \multirow{3}{*}{$\begin{array}{r}\text { Methods to approach the study } \\
\text { of seat capacity patterns }\end{array}$} & Final remarks \\
\hline & Acknowledgements \\
\hline & References \\
\hline
\end{tabular}

\section{Introduction}

Air transport has had a dramatic impact on the way we conceive of space and time. According to Harvey (1990), each distinctive mode of production or social formation will embody a distinctive bundle of time and space practices and concepts. In addition, technological evolution has had tremendous effects on the geography of space and time. In this regard, space-time convergence is one of the most spectacular effects of transport and communication technologies. In fact, it is difficult to have a single and objective sense of time and space independently of material processes, which reproduce social life. 
Transportation systems have been an intrinsic element in any human society and are the means by which materials, products, people and other tangible entities are transferred from one place to another. In the same vein, communications systems are the means by which information is transmitted from one place to another in the form of ideas, instructions, images, and so on. Developments in both systems have transformed the world, allowing unprecedented mobility of materials, products, people and markets (Dicken, 2003). In this regard, societies have become increasingly dependent on their transport systems to support their activities (Rodrigue et al., 2009). In other words, networks are the structure through which productive goods, social values and knowledge circulate. Information and communication technologies and transportation are present in any network built by economic actors (individuals, firms and organizations).

Since the application, implementation, impact and effect of space-shrinking technologies are not the same everywhere, space-time convergence is highly uneven. Additionally, technological developments have a strong tendency to be geographically concentrated (Dicken, 2003).

Uneven space-time convergence is also true for air transportation. Goetz (1992), Goetz and Sutton (1997), Bowen (2002), Zook and Brunn (2006) and others have proven that the geography of air accessibility has been significantly reshaped by deregulation: While the general consequence of deregulation is the increasing deconcentration of air service availability, which means that in absolute terms more people may benefit from their availability, in relative terms there is an increasing inequality in the distribution of these services, especially in terms of intercontinental connections.

Thus, uneven space-time convergence in air transportation is also echoed in power dimensions, since the structure and function of the world urban hierarchy is intimately associated with global patterns of aviation (Smith, 2001; Derudder and Witlox, 2005, 2008). Inequalities in air transportation will create unequal distributions of economic opportunity among regions and, at the same time, as with any human activity, air transport also generates negative externalities that are not equally distributed among all actors (see, for example, Suau-Sanchez et al., 2011, on noise externalities).

The reshaping and changes of global air traffic flows also unfold in lower scales of material experience. Locations with optimal air accessibility obtain significant competitive advantages over other regions (Cooke and Morgan, 1998). Airports are engines for regional economic development; thus, capital and knowledge cluster around airports, changing the production of physical infrastructure and land-use configurations on a regional scale. Concepts such as «aerotropolis» represent these emerging patterns of spatial concentration.

This paper reviews the literature on the uneven patterns of seat capacity in order to find out if deregulation and liberalization of air traffic markets has fostered concentration or deconcentration of air travel possibilities and, therefore, know whether economic power and development has become more or less concentrated. 


\section{Deregulation and liberalization}

Until the end of the seventies, international air transport was dominated by a regime of bilateral air service agreements between national governments. In 1978, with the signature of the US Airline Deregulation Act, there was the first step towards the deregulation of the air transport market. The US progressively deregulated its domestic market until 1985 when all controls over domestic routes and ticked prices were brought to an end. Regarding Europe, the deregulation of air transport, through the establishment of a single intra-European market, was by the agency of three interlinked deregulation packages, known as the first (1987), second (1990) and third (1993) packages, which effects where not fully applicable until the end of the 1990s. Concerning international bilateral air service agreements, the EU-US Open Sky Agreement of 2008 opened a new phase, in which carriers registered in the EU or the US have the right to operate services between any EU and US points.

After liberalization, airlines may freely configure their networks, choose the airports where they operate, frequencies, capacities and fares. To this point, contradictory forces can lead to concentration or deconcentration patterns of air traffic. First of all, airlines may take benefit from concentrating their traffic in a few airports (hubs) to exploit density economies, which imply the decrease in average costs from increasing traffic at the route level. While network airlines may take advantage of density economies by focusing traffic in their hub airports, low-cost carriers may prefer to focus their operations in a number of airport bases to save additional fixed costs that come from operating in additional airports (scale economies).

Although airlines have incentives to concentrate their traffic in a few airports, this does not necessarily mean that we should find a general tendency towards concentration because those airlines may use different airports in the hierarchy. It is true that local demand can be higher in large airports. However, large airports may be congested (see Brueckner (2002) for analysis of carrier behavior in congested airports and Flores-Fillol (2010) for congested hubs) and environmental and urban pressure (Suau-Sanchez et al., 2011) may limit capacity. Airlines may prefer to avoid competition through the dominance of the airports where they operate and, at least in Europe, the threat of foreign airlines entering at neglected national airports may push former flag carriers to follow a pre-emption strategy and disperse their network structure.

\section{Methods to approach the study of seat capacity patterns}

There are various concentration and dispersion indices to measure the spatial distribution of seat capacity among an airport population, such as the Concentration Ratio (CR) and the Herfindahl-Hirschman index (HHI) (Wojahn, 2001; Reynolds-Feighan, 1998; Suau-Sanchez and Burghouwt, $2011 \mathrm{a})$, the coefficient of variation and Theil's entropy measure and the Gini index (Reynolds-Feighan, 2001; Burghouwt et al., 2003). The advan- 
tages and disadvantages of the various concentration and dispersion measures have been frequently addressed in the literature (Reynolds-Feighan, 1998). Recently, alternatives to these standard concentration indices have been applied in order to "decode» the spatiality and complexity of air transport networks (Limtanakool et al., 2007; Martín and Voltes-Dorta, 2008; Derudder and Witlox, 2009; Paleari et al., 2010).

Most dispersion indices are useful to gain insight into the level of concentration of particular airline networks. However, to have a clear picture of which are the engines and determinants for market concentration and deconcentration, some studies conduct additional analyses by decomposing the Gini by airport size subgroup — which makes possible to determine the contribution of various population subgroups to the overall concentration of seat capacity - and airline type - which makes possible to measure the contribution of a particular airline network configuration to the overall concentration of seat capacity. This is the case of Burghouwt (2007), Reynolds-Feighan (2007b), Suau-Sanchez (2011) and Suau-Sanchez et al. (2012).

\section{Towards concentration or deconcentration?}

The literature review shows evidence of simultaneous forces of concentration and deconcentration (see table 1). Let us summarize the results by geographic area.

From a more global perspective, O'Connor's (2003) analysis shows a dispersal pattern: traditional hubs lost out in favor of slightly smaller, large cities between 1990 and 2000. However, Bowen (2002) for the 1986-1996 period saw a slight different picture: while overall more cities are more directly tied to international airline networks, poorest countries worsened their relative access to them.

For the US, some authors pointed out that the adoption of hub-and-spoke networks has led to air-traffic growth at fewer airports (Goetz and Sutton, 1997; Reynolds-Feighan, 1998, 2001; Goetz and Vowles, 2009). More particularly, Reynolds-Feighan (2007a) found a spatial concentration of US domestic traffic between 1990 and 1997 followed by a decrease of spatial concentration between 1997 and 1998, and relative stability until 2002. However, for the earlier period of the US deregulation act, from 1978 to 1989, Chou (1993) did not find sufficient evidence of a spatial concentration in the availability of air services by the increase of hub operations.

For Europe, some studies found a deconcentration in intra-EU seat capacity between 1990 and 2003 due to the growth of regional and low-cost airlines, which make use of smaller airports in the hierarchy, while an increasing concentration for extra-EU seat capacity at a limited number of large hub airports because of the network strategies of global airline alliances (Burghouwt and Hakfoort, 2001; Burghouwt et al., 2003; Burghouwt, 2007) ${ }^{1}$. In his line, Redondi et al. (2011) identify several airports that were de-hubbed between

1. See also Dobruszkes (2006) for a geography of low-cost networks. 
Table 1. Summary of airport capacity inequality studies for the EU and the US.

\begin{tabular}{lccc}
\hline & & \multicolumn{2}{c}{ Europe } \\
\cline { 3 - 4 } \multicolumn{1}{c}{ Authors } & Period of analysis & Intra-EU & Extra-EU \\
\hline Chou (1993) & $1978-1989$ & - & - \\
& & & - \\
Goetz and Sutton (1997) & $1978-1993$ & - & - \\
Bowen (2002) & $1984-1996$ & -
\end{tabular}

\begin{tabular}{|c|c|c|c|}
\hline Reynolds-Feighan (1998) & $1960-1984$ & - & - \\
\hline Reynolds-Feighan (2001) & 1969-1999 & - & - \\
\hline $\begin{array}{l}\text { Papatheodorou and Arvanitis } \\
\text { (2009) (Only Greece) }\end{array}$ & $1978-1991$ & $\begin{array}{l}\text { Stability } \\
\text { (Domestic) }\end{array}$ & $\begin{array}{l}\text { Deconcentration } \\
\text { (International) }\end{array}$ \\
\hline O'Connor (2003) & $1990-2000$ & - & - \\
\hline $\begin{array}{l}\text { Reynolds-Feighan } \\
\text { (2007a) }\end{array}$ & 1990-2002 & - & - \\
\hline
\end{tabular}

\begin{tabular}{|c|c|c|c|}
\hline $\begin{array}{l}\text { Burghouwt and Hakfoort (2001) } \\
\text { Burghouwt et al. (2003) } \\
\text { Burghouwt (2007) }\end{array}$ & $1990-2003$ & Deconcentration & Concentration \\
\hline Suau-Sanchez (2011) & 1990-2009 & Deconcentration & Concentration \\
\hline \multicolumn{4}{|l|}{ Suau-Sanchez et al. (2012) } \\
\hline Reynolds-Feighan (2007b) & 1996-2006 & \multicolumn{2}{|c|}{ Deconcentration (overall) } \\
\hline $\begin{array}{l}\text { Suau-Sanchez and Burghouwt } \\
\text { (2011) (only Spain) }\end{array}$ & 2001-2008 & Deconcentration & $\begin{array}{l}\text { Depending on the } \\
\text { destination market }\end{array}$ \\
\hline $\begin{array}{l}\text { Jimenez et al. (2012) (only } \\
\text { Portugal) }\end{array}$ & $2001-2010$ & Deconcentration & Concentration \\
\hline Bel and Fageda (2010) & $2004-2008$ & Deconcentration & Deconcentration \\
\hline Huber (2009) & 2005 & Deconcentration & Concentration \\
\hline
\end{tabular}

1997 and 2009 and did not recover their hub activity, which translates in higher levels of concentration. However, for a shorter period (2004-2008) Bel and Fageda (2010) recognized, in a set of large European urban areas, a deconcentration of intercontinental flights due to hub-bypassing strategies of selected network airlines. In this regard, Huber (2009), in his 2005 cross-sectional analysis, found a higher concentration of intercontinental seat capacity in Europe than in the US, although US intercontinental traffic also remained concentrated in a few airports. 


\begin{tabular}{|c|c|c|c|}
\hline \multicolumn{2}{|c|}{ United States } & \multirow[b]{2}{*}{ Global } & \multirow[b]{2}{*}{ Variable } \\
\hline Intra-US & Extra-US & & \\
\hline $\begin{array}{l}\text { No evidence of } \\
\text { concentration }\end{array}$ & - & - & Passenger traffic \\
\hline Concentration & - & - & Passenger traffic, air fares \\
\hline- & - & $\begin{array}{l}\text { Deconcentration } \\
\text { (in absolut terms) } \\
\text { Concentration } \\
\text { (in relative terms) }\end{array}$ & Airline routes and seat capacity \\
\hline Concentration & - & - & Seat capacity \\
\hline Concentration & - & - & Seat capacity \\
\hline- & - & - & Passenger traffic \\
\hline- & - & Deconcentration & Passenger traffic \\
\hline $\begin{array}{l}\text { Concentration } \\
(1990-1997)\end{array}$ & - & - & Seat cacapacity \\
\hline \multicolumn{4}{|l|}{$\begin{array}{l}\text { Deconcentration } \\
(1997-1998)\end{array}$} \\
\hline \multicolumn{4}{|c|}{ Stability (1998-2002) } \\
\hline- & - & - & Seat capacity \\
\hline Deconcentration & Concentration & - & Seat capacity \\
\hline \multicolumn{2}{|c|}{ Deconcentration (overall) } & - & Seat capacity \\
\hline- & - & - & Seat capacity \\
\hline- & - & - & Operations \\
\hline- & - & - & Seat capacity \\
\hline Concentration & Concentration & - & Seat capacity \\
\hline
\end{tabular}

In a study covering both the US and the EU, Suau-Sanchez (2011) and Suau-Sanchez et al. (2012), found that, for the 1990-2009 period, both intraEU and intra-US seat capacity deconcentrated, in other words, inequality decreased within the internal continental market. Regarding extra-EU and extra-US seat capacity, they found a concentration pattern, in other words, inequality increased for intercontinental travel. This study also looked into the airport hierarchy. In this regard, it found that extra-EU seat capacity concentration took place in the 1 st tier, although some 4th-tier airports ben- 
efited from new strategies that complement the traditional hub-and-spoke network configuration. This finding solves the apparent contradictory results of Burghouwt (2007), who found a concentration pattern, and Bel and Fageda (2010), who found a deconcentration pattern.

For South America, Lipovich (2010), adding a new dimension to the analysis, compares the concentration of the air traffic market with the one of the urban structure. He founds that in the MERCOSUR (Mercado Común del Sur) and the CAN (Comunidad Andina de Naciones) the air traffic market is more concentrated than the urban structure, which indicates a disadvantage for the medium and small size urban communities.

There is a flurry of research on the African case; yet, the studies of Akpoghomeh (1999) on the evolution of the Nigerian air traffic market and Pirie (2006) on the South African case stand out. The findings for Nigeria are clear, while before the deregulation the network pattern was very homogeneous, after the mid-1980's partial deregulation the pattern became highly concentrated in Lagos. For South Africa the results are similar to the ones of Europe and the US. From 1994 to 2003 there was a deconcentration in the intra-continental market, while a concentration at the intercontinental level.

Regarding Asia and Middle East, research has been more centered on hub connectivity analyses. Yet, from those studies one can deduct that seat capacity is highly concentrated at main hub airports and gateways in a clear strategy to become dominant global players (see, for example, O'Connell (2011) for the Middle East; and De Wit et al. (2009) for the Asia-Pacific). Nevertheless, in Southeast Asia, growth of intra-continental traffic keeps on benefiting an increasing number of airports as GDP grows and economic development is spread all over the region (Rimmer, 2000).

\section{Final remarks}

All studies agree that, in general terms, overall and intra-continental seat capacity has tended to deconcentrate, while inter-continental seat capacity has tended to be concentrated in fewer number of airports. Hence, we could say that airlines reacted to deregulation by changing their spatiotemporal network organization, which, at the same time, impacted on the availability of air services among airports. In quantitative terms, inequality decreased, since more air services from more airports are available. However, we could conclude that in qualitative terms inequality has increased, since the most valuable air services for the exchange of face-to-face information and supply chains, namely intercontinental air services, are more concentrated in fewer airports.

\section{Acknowledgements}

This research was partly developed at the Department of Geography of the Universitat Autònoma de Barcelona and supported by the Spanish Ministry 
of Science and Innovation (Grants SEJ2006-04023 and CSO2010-17178) and the Catalan Agency for management of University and Research Grants (Grant 2009SGR0106).

\section{References}

Акрояномен, O.S. (1999). "The development of air transportation in Nigeria». Journal of Transport Geography, 7, 135-146.

BeL, G. and Fageda, X. (2010). "Intercontinental flights from European airports: Towards hub concentration or not?». International Journal of Transport Economics, 37 (2), 133-153.

Bowen, J. (2002). «Network change, deregulation, and access in the global airline industry». Economic Geography, 78 (4), 425-439.

BRUECKNER, J.K. (2002). "Airport congestion when carriers have market power». The American Economic Review, 92 (5), 1357-1375.

Burghouwt, G. (2007). Airline Network Development in Europe and Its Implications for Airport Planning. Aldershot: Ashgate.

Burghouwt, G. and Hakfoort, J. (2001). «The European aviation network, 19901998». Journal of Air Transport Management, 7 (5), 311-318.

Burghouwt, G.; Hakfoort, J. and Van ECK, J.R. (2003). «The spatial configuration of airline networks in Europe». Journal of Air Transport Management, 9 (5), 309-323.

Chou, Y.H. (1993). «Airline deregulation and nodal accessibility». Journal of Transport Geography, 1 (1), 36-46.

Cooke, P.N. and Morgan, K. (1998). The Associational Economy: Firms, Regions, Innovation. Oxford: Oxford University Press.

Derudder, B. and Witlox, F. (2005). "An appraisal of the use of airline data in assessing the world city network: a research note on data». Urban Studies, 42 (13), 2371-2388.

- (2008). «Mapping world city networks through airline flows: context, relevance, and problems». Journal of Transport Geography, 16 (5), 305-312.

- (2009). "The impact of progressive liberalization on the spatiality of airline networks: a measurement framework based on the assessment of hierarchical differentiation». Journal of Transport Geography, 17 (2), 276-284.

De Wit, J.; Veldhuis, J.; Burghouwt, G. and Matsumoto, H. (2009). "Competitive position of primary airports in the Asia-Pacific Rim». Pacific Economic Review, 14, 639-650.

Dicken, P. (2003). Global Shift (fourth edition). London: Sage.

Dobruszkes, F. (2006). "An analysis of European low-cost airlines and their networks». Journal of Transport Geography, 14, 249-264.

Flores-Fillol, R. (2010). "Congested hubs». Transportation Research Part B, 44 (3), 358-370.

Goetz, A.R. (1992). "Air passenger transportation and growth in the U.S. urban system. 1950-1987». Growth and Change, 23 (2), 217-238.

Goetz, A.R. and Sutton, C. (1997). "The geography of deregulation in the US airline industry». Annals of the Association of American Geographers, 87 (2), 238-263.

Goetz, A.R. and Vowles, T.M. (2009). "The good, the bad, and the ugly: 30 years of US airline deregulation». Journal of Transport Geography, 17, 251-263.

Harvey, D. (1990). The Condition of Postmodernity. Oxford: Blackwell. 
Huber, H. (2009). "Comparing spatial concentration and assessing relative market structure in air traffic». Journal of Air Transport Management, 15, 184-194.

Limtanakool, N.; Dijst, M. and Schwanen, T. (2007). "A theoretical framework and methodology for characterizing national urban systems on the bases of flows of people: empirical evidence for France and Germany». Urban Studies, 44 (11), 2123-2145.

Jimenez, E.; Claro, J. and Pinho de Sousa, J. (2012). "Spatial and commercial evolution of aviation networks: a case study in mainland Portugal». Journal of Transport Geography, 24, 383-412.

Lipovich, G. (2010). Los aeropuertos de Buenos Aires y su relación con el espacio metropolitano. Buenos Aires: Universidad de Buenos Aires. Tesis doctoral.

Martín, J.C. and Voltes-Dorta, A. (2008). "Theoretical evidence of existing pitfalls in measuring hubbing practices in airline networks». Networks and Spatial Economics, 8 (2-3), 161-181.

O'Connell, J.F. (2011). "The rise of the Arabian Gulf Carriers: An insight into the business model of Emirates Airline». Journal of Air Transport Management, 17, 339-346.

O'Connor, K. (2003) «Global air travel: toward concentration or dispersal?». Journal of Transport Geography, 11 (2), 83-92.

Paleari, S.; Redondi, R. and Malighetti, P. (2010). «A comparative study of airport connectivity in China, Europe and the US: which network provides the best service to passengers?». Transportation Research Part E, 42 (2), 198-210.

Pirie, G. (2006). "Africanisation” of South Africa's international air links, 19942003». Journal of Transport Geography, 14 (1), 3-14.

Papatheodorou, A. and Arvanitis, P. (2009). "Spatial evolution of airport traffic and airport transport liberalization: the case of Greece». Journal of Transport Geography, 17, 402-412.

Redondi, R.; Malighetti, P. and Paleari, S. (2011). "De-hubbing of airports and their recovery patterns». Journal of Air Transport Management, 18, 1-4.

Reynolds-Feighan, A. (1998). "The impact of US airline deregulation on airport traffic patterns». Geographical Analysis, 30 (3), 234-253.

- (2001). "Traffic distribution in low-cost and full-service networks in the US air transportation market». Journal of Air Transport Management, 7 (5), 265-275.

- (2007a). "Competing networks, spatial and industrial concentration in the US airline industry». Spatial Economic Analysis, 2 (3), 237-257.

- (2007b). "Carrier network structures and the spatial distribution of air traffic in the European air transport market, 1996-2006». Rivista di Politica Economica, I-II, 243-270.

Rimmer, P.J. (2000). "Effects of the Asian Crisis on the geography of Southeast Asia's air traffic». Journal of Transport Geography, 8, 83-97.

Rodrigue, J.-P.; Comtois, C. and SLACK, B. (2009). The geography of transport systems. New York: Routledge. Second Edition.

Sмiтh, D. (2001). «World City Networks and Hierarchies, 1977-1997: An empirical analysis of global air travel links». American Behavioral Scientists, 44, 1656-1678.

Suau-Sanchez, P. (2011). Unevenness in Air Transportation: A Multi-scalar Analysis. Bellaterra: Universitat Autònoma de Barcelona. PhD Thesis.

Suau-Sanchez, P. and Burghouwt, G. (2011). "The geography of the Spanish airport system: spatial concentration and deconcentration patterns in seat capacity distribution, 2001-2008». Journal of Transport Geography, 19 (2), 244-254. 
Suau-Sanchez, P.; Pallares-Barbera, M. and Paül, V. (2011). «Incorporating annoyance in airport environmental policy: noise, societal response and community participation». Journal of Transport Geography, 19 (2), 275-284.

Suau-Sanchez, P.; Burghwout, G. and Fageda, X. (2012). Determinants for seat capacity distribution in the EU and the US, 1990-2009. Working paper.

Wojahn, O.W. (2001). Airline networks. Frankfurt am Main: Peter Lang, Europäischer Verlag der Wissenschaften. PhD Thesis.

Zook, M.A. and Brunn, S.D. (2006). «From Podes to Antipodes: Positionalities and Global Airline Geographies». Annals of the Association of American Geographers, 96, 471-490. 